\title{
WORKING CAPITAL OF THE RUSSIAN ECONOMY
}

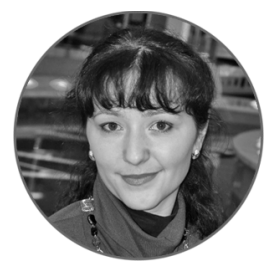

Article history:

Received 18 April 2017

Received in revised form

11 May 2017

Accepted 19 May 2017

Translated 29 November 2017

Available online 14 December 2017

JEL classification: E43, G21, G31

Keywords: working capital, financial condition, equity, borrowed resources

\begin{abstract}
Importance The article discusses the state of working capital of the Russian economy.

Objectives The article aims to study various aspects of working capital of the Russian economy and its sources, and develop recommendations to address the problem of insufficient working capital and optimize the structure of the sources.

Methods For the study, I used methods of systems, logical and statistical analyses, classification and synthesis.

Results I assess some indicators of working capital by major economic activity and industry, showing an unsatisfactory structure of working capital. The paper contains certain recommendations and proposals to address the problem.

Conclusions and Relevance Most Russian enterprises lack their own sources of working capital. Bank loans constitute the principal source of borrowings, which hinders the production and economic activity due to high interest rates.
\end{abstract}

The priority goal of any enterprise is to ensure the sufficient working capital for its smooth and continuing operations. In most industries enterprises dramatically lack working capital after economic relationships in Russia have transformed for the recent two decades.

To avoid any confusion of terminology, I should note that during the Soviet period the word combination working capital' ('oborotnyi kapital' in Russian, or circulating capital) was inconsistent with the socialist

\footnotetext{
${ }^{\dagger}$ For the source article, please refer to: Ермилина Д.А. Оборотные средства российской экономики. Финансовая аналитика: проблемы и решения. 2017. Т. 10. Вып. 7. С. 755-766.

URL: https://doi.org/10.24891/fa.10.7.755

*Translator's Note: The author hereinafter intends to define the terms given in italics from perspectives of the Russian language and illustrates how they are understood in Russia. Some of the Russian wordings do not have matching equivalents in English. The translator has to render the non-matching wordings as distinctively as possible, though keeping their differentiation and understanding their overlapping use.
}

economy and substituted with the term circulating resources ('oborotnye sredstva' in Russian).

Most Russian scholars equate both notions, though they do have distinctions. The issue remains disputable and controversial due to a variety of definitions working capital (circulating capital), working assets and circulating resources. As the most current meaning, circulating resources are interpreted as means of production (raw materials, inventories, fuel), which are completely consumed in each production cycle, losing and modifying their natural form ${ }^{1}$.

Working capital (circulating capital) is viewed as interpreted by Karl Marx, i.e. it is a part of productive capital, the value of which is totally carried to goods [1].

\footnotetext{
${ }^{1}$ Bol'shaya sovetskaya entsiklopediya. Pod. red. B.A. Vvedenskogo. 2 izd [Unabridged Soviet Encyclopedia. Edited by B.A. Vvedenskii. Second Edition]. Moscow, Grand Soviet Encyclopedia, 1954, vol. 30, p. 370. (In Russ.)
} 
There is a subtle difference between the economic concepts working capital and circulating resources.

The term working assets is more common for accounting ${ }^{2}$. They mean standardized and non-standardized circulating resources of the enterprise, which are carried in the balance sheet as assets ${ }^{3}$.

Unfortunately, contemporary economists insufficiently study and analyze working capital. The Soviet economist V.L. Perlamutrov performed the most in-depth analysis of this concept [2].

I should point out that the Soviet and contemporary statistical reports interpret working capital in a different way. As formulated in the Soviet statistical books, working capital means circulating resources, the structure of which includes commodities and materials, goods shipped and services delivered, cash, receivables and other circulating resources ${ }^{4}$.

In contemporary literature on statistics, working capital is equated with working assets, with inventories, short-term financial investment and cash being principal items.

In this article, the above economic categories are used as synonyms. I examine their common and different traits in my previous research [3, pp. 214-223].

Non-borrowed and raised resources are known to make up circulating resources. If the equity prevails among the total sources of working capital, the entity is stable and financially independent. However, it requires a certain level of financial sustainability.

According to official statistics, the Russian economy faces the financial crisis. Principal financial ratios corroborate the statement (Table 1). Hence, it is not sensible to talk about the financial independence of the Russian entities.

\footnotetext{
${ }^{2}$ Order of the Russian Ministry of Finance On Approval of the Accounting Regulation - Financial Statements of the Entity (PBU 4/99) of July 6, 1999 № 43H

${ }^{3}$ Bol'shoi ekonomicheskii slovar'. Pod red. A.N. Azrieliyana. 6 izd [Unabridged Dictionary of Economics. Edited by A.N. Azrieliyan. Sixth Edition]. Moscow, Institute of New Economics Publ., 2004, p. 27. (In Russ.)

${ }^{4}$ Narodnoe khozyaistvo SSSR 1922-1972 gg.: statisticheskii sbornik [National Economy of the USSR 1922-1972: A Statistical Book]. Moscow, Statistika Publ., 1972, p. 470. (In Russ.)
}

Throughout the entire analyzable period, the ratios remained within the range of regulatory values. Financial sustainability metrics of manufacturing enterprises lag behind the same metrics of mineral production enterprises.

The analyzable indicators worsen. The Russian laws set up 2 as the regulatory value of the current ratio, but it actually equals 1.28 and 1.27 in 2012 and 2015 respectively.

Globally, optimal values of the current ratio range from 1.5 to $2.5[4,5]$. But the Russian economy has not reached the optimal lower bound for more than 20 years (in 1995 and 2005 the current ratio was 1.15 and 1.22 respectively) ${ }^{5}$.

Downward changes in the equity-to-assets ratio signify the growing dependence of the Russian economy on external sources of finance. It is mainly typical of manufacturing enterprises. In 2012, the equity-to-assets ratio of manufacturing industries was twice as low as the same indicator of the mineral production sector.

For purposes of the research, it is valuable to analyze the ratio of net working capital to working assets. Throughout the entire contemporary history, the ratio becomes negative in the economy as a whole and by type of economic activities (Table 2), meaning that the formation of working assets is distorted.

I should mention that the shortage of circulating resources and subsequent crisis phenomena deteriorated over time. Economically, the negative ratio of net working capital to working assets means that entities do not have net working capital at all. Multiplying this ratio and working assets (the transformation of the initial formula), I arrive at the value that can be construed as the company's outstanding bank interests to be capitalized and subject to interests [6, p. 19].

In 2015, working capital deficit severely affected such segments as Hotels and Restaurants, Transport and Communications, Manufacturing Sector. Furthermore, in 2015, the ratio demonstrated

\footnotetext{
${ }^{5}$ Rossiiskii statisticheskii ezhegodnik. 2000: statisticheskii sbornik [Russian Statistical Yearbook. 2000]. Moscow. Goskomstat Rossii Publ., 2000, p. 532 (In Russ.); Rossiiskii statisticheskii ezhegodnik. 2007: statisticheskii sbornik [Russian Statistical Yearbook. 2007]. Moscow, Goskomstat Rossii Publ., 2007, p. 683. (In Russ.)
} 
a slump in all the segments as compared with 2010, thus proving an increase in the debt burden of enterprises.

It is reasonable to analyze circulating resources in the manufacturing sector. The manufacturing sector is traditionally considered as the innovative platform for the economy. For reference: innovation expenses account for 4.6 percent in the mineral production sector, 24.6 percent in the manufacturing sector, 4.7 percent in the electric power engineering, and 15 percent in communications out of total investment ${ }^{6}$.

That is why the priority goal is to provide manufacturing enterprises with sufficient circulating resources so as to implement the principal objectives of the Industrial Policy Program of the Russian Federation?

The ratio of net working capital to working assets of manufacturing sector is below than its overall value in the economy. In 2015, the chemical and petrochemical sector, ferrous and non-ferrous metallurgy experience the most severe working capital deficit. The light industry is less exposed to this process.

It is noteworthy that all industries and types of economic activities have their own technological distinctions that influence flows of working capital and performance.

In 2015, the cycle of working assets took 157 days, whereas it did 212 and 136 days in the manufacturing sector and trade respectively ${ }^{8}$.

Considering the retail trade separately, this indicator takes from one to two months. A longer turnover period basically aggravates business and financial risks. The more turnover cycles take place within a year, the higher revenue trading entities have in comparison with industrial enterprises. Thus, trade

\footnotetext{
${ }^{6}$ Rossiiskii statisticheskii ezhegodnik. 2016: statisticheskii sbornik [Russian Statistical Yearbook. 2016]. Moscow, Rosstat Publ., 2016, p. 572, p. 578. (In Russ.)

${ }^{7}$ Resolution of the Russian Government On Approval of the State Program of the Russian Federation - The Development of the Industry and Increase in its Competitiveness of April 15, 2014 № 328.

${ }^{8}$ Finansy Rossii. 2016: statisticheskii sbornik [Finance of Russia. 2016. Statistical Yearbook]. Moscow, Rosstat Publ., 2016, pp. 198-199. (In Russ.)
}

intermediaries have better profit and profitability metrics.

Please refer to Table 3 for more details on the formation of working assets in manufacturing, mineral production and trading enterprises.

As I calculate, interests payable of companies significantly exceed a growth rate of working assets. The manufacturing sector faces the toughest situation, with respective interests payable being 13 times as high as their working assets. Mineral production enterprises have the best indicators. Their capitalized debt rises 1.28 times as fast as working assets. Total borrowings increase 1.25 times as fast as working assets in the economy as a whole, and 1.05, 1.4 and 1.01 times as fast as working assets in mining, manufacturing and trading sectors respectively.

Whereas a substantial growth in the debt burden is offset with a slight increase in working assets, manufacturing enterprises have no capabilities for adequate production and operations since they lack monetary resources. There is no decision concerning the way their competitiveness can be improved. Under the current circumstances, it is impossible to count on the prevalence of equity to form working capital.

It is worth mentioning that it is impossible to determine the ratio of equity and borrowed funds needed to construct working capital of the Russian economy as a whole and per type of principal economic activities and industry. Such data are simply unavailable in the contemporary official statistics.

The Soviet economy tended to have an equal proportion of equity and borrowed funds, which still remains the best condition for forming circulating resources in industrially developed countries.

In the USSR official statistics for 1960 and 1970, equity and other sources regarded as equity accounted for 47.7 and 38.8 percent respectively, with 39.2 and 43.6 percent of bank loans ${ }^{9}$.

Although the equity and borrowed sources of circulating resources were in the approximate

\footnotetext{
${ }^{9}$ Narodnoe khozyaistvo SSSR 1922 - 1972 gg.: statisticheskii sbornik [National Economy of the USSR 1922-1972: A Statistical Book]. Moscow, Statistika Publ., 1972, p. 471. (In Russ.)
} 
balance, the borrowed sources included not only bank loans but also other receivables and sources, being gratuitous contributions.

Despite high inflation rates and expensive loans, the equity is being substituted with borrowed sources of circulating resources in Russia. While the profitability of most domestic enterprises' products is below the interest rate (Table 4), the banking system exerts pressure on corporate finance.

The weighted average interest rate on loans has not changed for the entire period in question. As for the profitability, it demonstrates a stable decline in all enterprises, other than agricultural ones.

The affordability of loan facilities is out of question, assuming that the key interest rate is less than the profit margin. Nevertheless, many entities still use loans as the main source for replenishing their working capital, despite its expensiveness.

I should mention that borrowing costs are not the same for various groups of entities. On the one hand, free pricing (tariffs) enables enterprises in trading, mineral production and electrical power engineering to compensate their expenses for raising loans with customers' payments, thus alleviating their debt burden. On the other hand, this distinction triggers a growth in the lending rate without having any special detrimental effect on them.

However, short-term loans account for a more and more considerable share in total loan facilities granted to entities, thus indirectly pointing to the problem of the effective formation of the Russian entities' working capital (Table 5).

It is evidence that short-term loans are utilized to ensure continuous operations, including the replenishment of circulating resources. Whereas would-be borrowers (entities) have no other sources of finance, they agree upon enslaving terms credit institutions offer, thus plunging into an even deeper crisis and dependence.

The fact that the Russian entities replenish their circulating resources with accrued depreciation reflects the severe distortion of the way circulating resources are formed. It is the only method for most entities to solve urgent matters and ensure their uninterrupted operations. These assertions are supported in Tables 6 and 7.

In case of an inexhaustible pool of resources, depreciation charges constitute an amount to be included into the cost of finished goods in line with the opening value of fixed assets. According to Table 6, factual and statutory depreciation charge diverge.

As shown in Table 7, RUB 7,417.17, or 60.85 percent of standard-compliant capabilities, are idle in the economy. Furthermore, the Russian entities tend to raise the share of depreciation charges used for purposes other than core activities, including the replenishment of working capital. For reference: in 2007, depreciation, which was not included into the cost, accounted for 56 percent of total depreciation charges ${ }^{10}$.

Treating profit as a source for financing circulating resources, it is important to remember that a healthy company uses profit to finance an increase in circulating resources only.

Profit contributes to the production expansion. If the entity finances its circulating resources using its profit during crises and stagnation, it means it consumes its net working capital. Accounting for 32.6 percent of the overall economy as of 2015 , unprofitable entities do not have this source of finance ${ }^{11}$.

When this happens, many Russian entities were caught in a trap of maintaining the required amount of circulating resources. Although there are two areas of traditional investment - long-term and short-term investment, the second one really works only since the major part of net profit (sometimes the entire profit) is often earmarked for servicing the production, rather than its retrofitting.

Thus entities are trapped in a vicious circle. Higher profitability and renewal of fixed assets can turn the situation for the better, thus expanding the depreciation basis and increasing non-borrowed sources of finance for current operations.

\footnotetext{
${ }^{10}$ Indicators for 2007 were measured by the authors referred to in point [7]

${ }^{11}$ Finansy Rossii. 2016: statisticheskii sbornik [Finance of Russia. 2016. Statistical Yearbook]. Moscow, Rosstat Publ., 2016, p. 98.
} 
However, it is difficult to realize since many production and business agents owe significant amounts to credit institutions. Net profit is utilized to settle those debts and provide the entity with circulating resources (short-term lending). Hence, the entity no longer can allocate its profit for the core activity needs, i.e. the expanded production. Here we return to the starting point.

Summing up the above conclusions, I can say that the contemporary economy of Russia vastly lacks circulating resources. This matter causes not only a production decline and all respective consequences, but also destabilizes the banking sector (the existence of a critical pool of uncollectible or bad debts. Refer to Table 3, line 4).

I can point out several solutions to the problem.

1. Special-purpose support to the real economy with funds earmarked as gratuitous aid to the banking system (2015: RUB 1 trillion) at the bearable lending rate.

According to S. Andryushin and V. Kuznetsova [8, p. 12], the crisis is impossible to overcome without a reform. As they believe, the Russian Government should, first of all, tackle bad loans by creating the appropriate infrastructure under the auspices of the Central Bank of Russia so as to effectively purge toxic assets from bank account balances.

2. If credit institutions finance technological retrofitting projects, on the one hand, it will enable the banking system to cease the primitive practice of immediate profiteering and opt for the long-term money strategy. On the other hand, entities will be able to expand their depreciation base and ample their non-borrowed sources of finance for the working capital. As S.V. Solov'eva expresses in her article, the policy of monetary regulators shall pursue the creation of favorable conditions for sustainable economic growth. The affordability of loans (inter alia long-term loans through the effective refinance system) and the mechanism for converting savings into investments are of paramount importance in this context [9, p. 5].

3. V. Daskovskii and V. Kiselev suggest setting up trading and industrial groups as a remedy for recovering both the production and banking sectors in Russia. In their opinion, uncollectible debts should not, by no means, be borne by the State [6, p. 25].

If industrial enterprises, which lack circulating resources and hold substantial debt liabilities, and credit institutions unite their efforts, they will mend the financial position of many entities. In this case, bad debts will cease to rise since banks will hold shares in pledged property, rather than debts. Therefore, all parties to such an association will benefit from trouble-free operations of entities.

4. According to the other suggestion for entities to raise additional working capital, the effective regulatory and legislative framework for financial and industrial groups should be created. Nowadays the relevant law was abolished ${ }^{12}$. Therefore, the law shall be re-enacted so that it would integrate all the best practices of such associations.

\footnotetext{
${ }^{12}$ Based on Federal Law On the Abolition of the Federal Law - On Financial and Industrial Groups of June 22, 2007 № 115-Ф3
} 
Table 1

Individual indicators of financial stability and liquidity of companies in the Russian economy in 2012-2015

\begin{tabular}{llllll}
\hline Indicator & Regulatory value & $\mathbf{2 0 1 2}$ & $\mathbf{2 0 1 3}$ & $\mathbf{2 0 1 4}$ & $\mathbf{2 0 1 5}$ \\
\hline Current ratio, total & $>2$ & 1.28 & 1.25 & 1.21 & 1.27 \\
\hline Mineral production & - & 1.7 & 1.51 & 1.52 & 1.41 \\
\hline Manufacturing enterprises & - & 1.42 & 1.31 & 1.31 & 1.43 \\
\hline The net working capital to working assets ratio, total & $>0.1$ & -0.26 & -0.31 & -0.41 & -0.42 \\
\hline Mineral production & - & -0.09 & -0.23 & -0.33 & -0.44 \\
\hline Manufacturing enterprises & - & -0.16 & -0.35 & -0.46 & -0.44 \\
\hline The equity-to-assets ratio, total & $>0.5$ & 0.48 & 0.45 & 0.4 & 0.4 \\
\hline Mineral production & - & 0.67 & 0.56 & 0.53 & 0.53 \\
\hline Manufacturing enterprises & - & 0.41 & 0.37 & 0.29 & 0.27 \\
\hline
\end{tabular}

* Regulatory values are prescribed by Resolution of the Russian Government of May 20,1994 № 498, On Some Measures for Enforcement of the Insolvency (Bankruptcy) Laws.

Source: Finansy Rossii. 2016 [Finance of Russia. 2016]. Moscow, Rosstat Publ., 2016, pp. 109-114. (In Russ.)

Table 2

The net working capital to working assets ratio in 1995-2015, percentage

\begin{tabular}{|c|c|c|c|c|c|}
\hline Sector & 1995 & 2000 & 2005 & 2010 & 2015 \\
\hline Overall economy & 14.2 & -7.4 & -12.5 & -14.1 & -42.6 \\
\hline Industries, total & 15.5 & -4.5 & -16.6 & -4.8 & -53.2 \\
\hline Mineral production & 1.2 & 1.5 & -34.6 & -13.1 & -43.9 \\
\hline $\begin{array}{l}\text { Manufacturing enterprises, total, } \\
\text { including }\end{array}$ & 12.3 & -14.7 & -3.4 & -8.2 & -44 \\
\hline - ferrous and non-ferrous metallurgy & 11.7 & 7.6 & 16.8 & -6.8 & -42.6 \\
\hline - chemical and petrochemical industry" & 18.6 & -6.3 & -8.7 & -19.1 & -53.7 \\
\hline - mechanical engineering and metal working & 12.7 & -14 & 2.5 & -2.3 & -9.3 \\
\hline - light industry & 11.5 & -31.5 & -12.1 & -9.4 & -7.8 \\
\hline - food industry & 13.6 & -29.3 & -14.1 & -19.1 & -17.2 \\
\hline Production and distribution of electrical power (gas, water) & 36.8 & 5 & -11.9 & 6.9 & -71.6 \\
\hline Wholesale and retail trade & 8.5 & -9.9 & -4.7 & 3.7 & -6.3 \\
\hline Transport and communications & 9.6 & -27.7 & -39.1 & -57.8 & -131.2 \\
\hline Agriculture & 36.7 & -10.5 & -3.2 & -36 & -33.7 \\
\hline Construction & 5.7 & -9.2 & -10 & -26 & -28.4 \\
\hline Financing activity & - & - & -7.7 & -17.4 & -45.4 \\
\hline Hotels and restaurants & & & -57 & -34.8 & -359.8 \\
\hline Public administration & & & -102.2 & -27.5 & 30.4 \\
\hline
\end{tabular}

Note. Matching of codes as a result of the abolition of the Soviet Union Classifier of Industries of the National Economy and adoption of the Russian Classifier of Types of Economic Activity as set forth in Resolution of the Russian Government of February 2, 2003 № 108 [5, pp. 40-46].

* The net working capital to working assets ratio was assessed as the weighted average value per type of economic activities, which are represented with several industries (for example, chemical and petrochemical sectors).

Source: Authoring 
Table 3

The structure of, and change in loans vs. working assets in 2005-2015

\begin{tabular}{|c|c|c|c|c|c|c|c|c|c|c|c|c|}
\hline \multirow[t]{2}{*}{ Indicator } & \multicolumn{3}{|c|}{ Overall economy } & \multicolumn{3}{|c|}{ Mineral production } & \multicolumn{3}{|c|}{ Manufacturing industries } & \multicolumn{3}{|c|}{$\begin{array}{l}\text { Wholesale and retail } \\
\text { trade }\end{array}$} \\
\hline & 2005 & 2010 & 2015 & 2005 & 2010 & 2015 & 2005 & 2010 & 2015 & 2005 & 2010 & 2015 \\
\hline $\begin{array}{l}\text { 1. Net working capital to working } \\
\text { assets ratio, } \%\end{array}$ & -12.5 & -14.1 & -42.6 & -34.6 & -13.1 & -43.9 & -3.4 & -8.2 & -44 & -4.7 & 3.7 & -6.3 \\
\hline 2. Working assets, billion RUB & 14,316 & 39,384 & 85,129 & 1,945 & 3,294 & 6,790 & 4,344 & 10,879 & 23,588 & 2,713 & 9,347 & 19,534 \\
\hline $\begin{array}{l}\text { 3. Capitalized amount payable } \\
\text { for interests, billion RUB (point } \\
1 \times \text { point } 2 \text { ) }\end{array}$ & 1,790 & 5,553 & 36,265 & 673 & 432 & 2,981 & 148 & 892 & 10,379 & 128 & -346 & 1,231 \\
\hline $\begin{array}{l}\text { 4. Loan, billion RUB (point } 2+ \\
\text { point 3) }\end{array}$ & 16,106 & 44,937 & 121,394 & 2,618 & 3,726 & 9,771 & 4,492 & 11,681 & 33,967 & 2,841 & 9,001 & 20,765 \\
\hline $\begin{array}{l}\text { 5. Growth in working assets } \\
\text { (2015vs. 2005), \% }\end{array}$ & 594 & & & 349 & & & 543 & & & 720 & & \\
\hline $\begin{array}{l}\text { 6. Growth in entities' interests } \\
\text { payable ( } 2015 \text { vs. 2005), \% }\end{array}$ & 202 & & & 443 & & & 701 & & & 962 & & \\
\hline $\begin{array}{l}\text { 7. Loan growth (2015 vs. 2005), } \\
\%\end{array}$ & 754 & & & 373 & & & 756 & & & 731 & & \\
\hline
\end{tabular}

Source: Authoring, based on [6]

\section{Table 4}

Product profitability at basic prices in comparison with the average interest rate on loans, percentage

\begin{tabular}{llll}
\hline \multirow{2}{*}{ Type of activity, parameter } & \multicolumn{3}{l}{ Product profitability at basic prices } \\
\cline { 2 - 4 } & $\mathbf{2 0 0 5}$ & $\mathbf{2 0 1 0}$ & $\mathbf{2 0 1 5}$ \\
\hline Overall economy & 13.5 & 10 & 8.1 \\
\hline Mineral production & 35.6 & 31.9 & 24.9 \\
\hline Manufacturing sectors & 15.3 & 14.8 & 11.9 \\
\hline Production and distribution of electric power, gas and water & 5.3 & 7.1 & 5 \\
\hline Wholesale and retail trade & 9.7 & 8.3 & 6.1 \\
\hline Transport and communications & 14.4 & 13.5 & 9.4 \\
\hline Agriculture & 6.7 & 9.1 & 20.7 \\
\hline Construction & 3.9 & 4.5 & 3.8 \\
\hline Weighted average interest rate on loans & 11.6 & 12 & 11.7 \\
\hline
\end{tabular}

Note. The interest rate is calculated on the basis of statistical data on the average interest rates on loans issued to non-financial organizations. Source: Rossiiskii statisticheskii ezhegodnik. 2016 [Russian Statistical Yearbook. 2016]. Moscow, Goskomstat Rossii Publ., 2016, p. 564; Rossiiskii statisticheskii ezhegodnik. 2006 [Russian Statistical Yearbook. 2006]. Moscow, Goskomstat Rossii Publ., 2006, p. 657; Rossiiskii statisticheskii ezhegodnik. 2011 [Russian Statistical Yearbook. 2011]. Moscow, Goskomstat Rossii Publ., 2011, p. 627; Byulleten'bankovskoi statistiki = Bulletin of Banking Statistics, 2006, no. 10, p. 123; Byulleten'bankovskoi statistiki = Bulletin of Banking Statistics, 2011, no. 8, p. 126; Statisticheskii byulleten'Banka Rossii = Statistical Bulletin of the Bank of Russia, 2016, no. 2, p. 120 (In Russ.) 
Table 5

Lending to the Russian economy

\begin{tabular}{lllll}
\hline Indicator & 2005 & 2010 & 2015 & $\begin{array}{l}\text { 2015 vs. 2005, } \\
\text { factor }\end{array}$ \\
\hline $\begin{array}{l}\text { The amount of loans issued to entities, other than governmental and } \\
\text { local authorities, governmental and extra-budgetary funds, billion } \\
\text { RUB }\end{array}$ & $30,768,322$ & $38,107,176$ & $249,650,725$ & 8.11 \\
\hline $\begin{array}{l}\text { Short-term loans (with the maturity date within a year inclusive), } \\
\text { billion RUB }\end{array}$ & $10,285,959$ & $11,687,814$ & $165,999,644$ & 16.1 \\
\hline \begin{tabular}{l} 
Specific weight of short-term loans out of total loans, percent \\
\hline
\end{tabular} & 33.4 & 30.7 & 66.5 & 2 \\
\hline
\end{tabular}

Source: Authoring, based on: Byulleten'bankovskoi statistiki = Bulletin of Banking Statistics, 2006, no. 10, p. 104; Byulleten'bankovskoi statistiki = Bulletin of Banking Statistics, 2011, no. 8, p. 116; Statisticheskii byulleten'Banka Rossii = Statistical Bulletin of the Bank of Russia, 2016, no. 2, p. 125

\section{Table 6}

The depreciation base of the Russian economy and depreciation charges in 2015

\begin{tabular}{|c|c|c|c|c|c|c|}
\hline \multirow[b]{2}{*}{ Indicator } & \multicolumn{6}{|c|}{ Fixed assets } \\
\hline & Buildings & Facilities & $\begin{array}{l}\text { Machinery and } \\
\text { equipment }\end{array}$ & Vehicles & Other & Total \\
\hline \multicolumn{7}{|l|}{$\begin{array}{l}\text { Types of fixed assets, depreciation base: } \\
\text { - percentage }\end{array}$} \\
\hline - billion RUB & $\begin{array}{l}14.7 \\
23,625.5\end{array}$ & $\begin{array}{l}49.6 \\
79,719.6\end{array}$ & $\begin{array}{l}28.2 \\
45,324.5\end{array}$ & $\begin{array}{l}5.4 \\
8,679.15\end{array}$ & $\begin{array}{l}2.1 \\
3,375.25\end{array}$ & $\begin{array}{l}100 \\
160,725\end{array}$ \\
\hline Depreciation rate $\%$ & 3.33 & 7 & 10 & 10 & 12.5 & - \\
\hline $\begin{array}{l}\text { Depreciation charges in case of } \\
\text { the complete base per all types of fixed } \\
\text { assets, billion RUB }\end{array}$ & 786.76 & $5,580.33$ & $4,532.45$ & 867.92 & 421.91 & $12,189,37$ \\
\hline $\begin{array}{l}\text { Depreciation that is actually included } \\
\text { into the cost of products, billion RUB }\end{array}$ & - & - & - & - & - & $4,772.2$ \\
\hline
\end{tabular}

* As per the classification of fixed assets included into depreciation groups.

Source:Authoring, based on: Finansy Rossii. 2016 [Finance of Russia. 2016]. Moscow, Rosstat Publ., 2016, p. 103; Rossiiskii statisticheskii ezhegodnik. 2006 [Russian statistical Yearbook. 2006]. Moscow, Goskomstat Rossii Publ., 2006, p. 31; [7, pp. 20-21]; Investitsionnaya deyatel'nost'v Rossii: usloviya, tendentsii, faktory [Investment activity in Russia: conditions, trends, factors]. Moscow, Rosstat Publ., 2016, p. 67

\section{Table 7}

The capacity, use and areas for depreciation in 2015

\begin{tabular}{lll}
\hline Indicator & Billion RUB & \% \\
\hline Depreciation charges in case of the complete base & $12,189.37$ & 100 \\
\hline Depreciation not included into the cost & $7,417.17$ & 60.85 \\
\hline Depreciation included into the cost & $4,772.2$ & 39.15 \\
\hline
\end{tabular}

Source : Authoring

\section{Acknowledgments}

The article was prepared within State job and basic research No. 0163-2016-0001, A Methodological Framework to Establish Sound Financial and Monetary Policy Parameters for Economic Security. 


\section{References}

1. Marx K., Engels F. Sochineniya. V $50 t$ [Selected works. In 50 volumes]. Moscow, Politizdat Publ., 1961, vol. 24, p. 188.

2. Perlamutrov V.L. Problemy ispol'zovaniya oborotnykh sredstv v promyshlennosti [Issues of the use of circulating assets in industry]. Moscow, Nauka Publ., 1973, 213 p.

3. Ermilina D.A. [The category of 'floating capital' in economic science]. Zhurnal ekonomicheskoi teorii = Journal of Economic Theory, 2016, no. 4, pp. 214-223. (In Russ.) URL: http://www.uiec.ru/content/zhurnal2015/22iErmilina.pdf

4. Lushenkova N.I. [Issues of methodology analysis of financial condition]. Mir nauki i obrazovaniya = World of Science and Education, 2016, no. 1(5), p. 6. (In Russ.)

URL: http://www.mgirm.ru/World_of_science_and_education/2016/1(5)/Lushenkova.pdf

5. Saifieva S.N. [A method of calculation and the efficiency of industry tax burden in 2000-2008]. Finansy = Finance, 2010, no. 12, pp. 40-46. (In Russ.) URL: http://www.ipr-ras.ru/articles/sajf11-01.pdf

6. Daskovskii V., Kiselev V. [The relationships of the real and banking sectors of economy]. Ekonomist, 2016, no. 1, pp. 15-29. (In Russ.)

7. Daskovskii V., Kiselev V. [Degradation and phenomena of the investment activities in Russia]. Investitsii v Rossii = Investments in Russia, 2009, no. 5, pp. 20-32. (In Russ.)

8. Andryushin S., Kuznetsova V. [The banking sector of Russia and its reform]. Voprosy Ekonomiki, 2009, no. 7, pp. 15-30. (In Russ.)

9. Solov'eva S.V. [Problems of investment and lending in the Russian economy in modern conditions]. Segodnya i zavtra rossiiskoi ekonomiki = Today and Tomorrow of Russian Economy, 2016, no. 77, pp. 5-12. (In Russ.)

\section{Conflict-of-interest notification}

I, the author of this article, bindingly and explicitly declare of the partial and total lack of actual or potential conflict of interest with any other third party whatsoever, which may arise as a result of the publication of this article. This statement relates to the study, data collection and interpretation, writing and preparation of the article, and the decision to submit the manuscript for publication. 